\title{
Uji Eksperimental Pengaruh Dimensi Lebar Rectifier Guide Vanes terhadap Kinerja Turbin Hidrokinetik Savonius
}

\author{
NUR ICHSAN, DWI ANUNG NINDITO, RADEN HARYO SAPUTRA
}

Program Studi Teknik Sipil, Universitas Palangka Raya, Indonesia

Email: dwi_anungnindito@eng.upr.ac.id

\begin{abstract}
ABSTRAK
Karakteristik blade sisi cekung turbin hidrokinetik Savonius yang memiliki nilai torsi negatif mengakibatkan kelemahan berupa efisiensi turbin yang relatif rendah, sehingga diperlukan sistem pengarah aliran berupa rectifier guide vane. Studi ini bertujuan membandingkan performa yang dihasilkan turbin Savonius tanpa guide vanes dan turbin Savonius menggunakan guide vanes dengan memvariasikan lebar rectifier $L=R t / 4, L=R t / 2$ dan $L=3 R t / 4$, dimana $R$ t adalah jari-jari turbin. Metode pengujian dilakukan secara eksperimental di saluran prismatik dengan kecepatan aliran 0,111-0,1415 m/s. Hasil studi menunjukkan bahwa penambahan guide vanes dengan variasi lebar rectifier $L=R t / 4, L=R t / 2$ dan $L=3 R t / 4$ masing-masing menghasilkan peningkatan torsi sebesar 29,9\%; 33,3\%; dan 36,3\%. Turbin Savonius menggunakan guide vanes dengan lebar rectifier $L=3 R t / 4$ menghasilkan coefficient of torque $\left(C_{t}\right)$ dan coefficient of power $\left(C_{p}\right)$ yang lebih tinggi dibandingkan variasi lebar rectifier (L) lainnya, sehingga kinerja turbin meningkat.
\end{abstract}

Kata kunci: coefficient of power, hidrokinetik, savonius, rectifier guide vanes

\begin{abstract}
The characteristic of the concave side blade of the Savonius hydrokinetic turbine which has a negative torque value, it leads to the weakness in the form of a relatively low turbine efficiency, thus a flow steering system is needed in the form of a rectifier guide vane. The aim of this study was to compare the performance of the Savonius turbine without guide vanes and the Savonius turbine using guide vanes by varying the width of the rectifier $L=R t / 4, L=R t / 2$ dan $L=3 R t / 4$, where $R t$ is the turbine radius. The test method was undertaken experimentally in a prismatic channel with a flow velocity of $0.111-0.1415 \mathrm{~m} / \mathrm{s}$. The results of the study pointed out that the addition of guide vanes with variations in the width of the rectifier was $L=R t / 4, L=R t / 2$ dan $L=3 R t / 4$ and each of them had an increase in torque of $29.9 \%, 33.3 \%$ and $36.3 \%$. The Savonius turbine used guide vanes with a rectifier width of $L=3 R t / 4$ and it resulted a higher coefficient of torque $\left(C_{t}\right)$ and coefficient of power $\left(C_{p}\right)$ compared to other variations of rectifier width $(L)$, thus, the performance of turbine increased.
\end{abstract}

Keywords: coefficient of power, hydrokinetic, savonius, rectifier guide vanes 


\section{PENDAHULUAN}

Permintaan yang terus meningkat terhadap energi listrik merupakan penggerak utama dalam pengembangan teknologi berbasis energi terbarukan. Energi hidrokinetik sangat menjanjikan sebagai sumber energi terbarukan yang ramah lingkungan. Turbin hidrokinetik dapat dijadikan sebagai teknologi untuk pembangkit listrik skala kecil pada kondisi topografi daerah tepi sungai yang memiliki head (tinggi jatuh) rendah (Nindito dan Kamiana, 2010). Turbin hidrokinetik pada umumnya dibagi menjadi 2 jenis, yaitu Horizontal Axis Turbine (HAT) dan Vertical Axis Turbine (VAT). Jenis-jenis Vertical Axis Turbine (VAT), seperti Darrieus, H-Darrieus, Spinning Top Darrieus (Wardani, Nindito, dan Jaya, 2020), Gorlov, Turbin DNA (Antomo, Kamiana, dan Nindito, 2020), Savonius dan Tornado Savonius (Yudistira, Nindito, dan Saputra, 2021). Jenisjenis Horizontal Axis Turbine (HAT), seperti Archimedes Spiral dan Archimedes Spiral dengan truncated cone dan ekor pengarah (Pratama, Nindito, dan Saputra, 2021).

Turbin Savonius merupakan tipe turbin yang memanfaatkan drag force (gaya seret). Karakteristik turbin Savonius memiliki ciri khas sendiri, dilihat dari bentuk pola aliran yang terjadi di sekitar turbin (Kang, Liu, dan Yang, 2014). Turbin Savonius memiliki kelemahan yaitu efisiensi yang relatif rendah karena memiliki karakteristik blade sisi cekung yang memiliki nilai torsi negatif yang cukup tinggi. Berbagai inovasi telah dilakukan untuk meningkatkan performa turbin Savonius, namun inovasi tersebut lebih menekankan pada sisi modifikasi parameter Aspek Rasio (AR), jarak overlap dan bentuk blade. Yudistira, Nindito, dan Saputra (2021) melakukan studi perubahan bentuk blade turbin Savonius dengan bentuk kerucut terpancung yang semakin mengecil ke bagian bawah. Bentuk blade yang mengikuti bentuk profil distribusi kecepatan mampu meningkatkan performa turbin terhadap nilai RPM. Upaya lain yang telah dilakukan untuk mengoptimalkan energi hidrokinetik yaitu dengan menggunakan saluran diffuser-augmented. Metode tersebut dapat memusatkan aliran dan lebih mempercepat aliran yang berada pada saluran mikro sehingga energi yang diserap oleh turbin meningkat (Elbatran et al., 2015). Roy, Mukherjee, dan Saha (2014) melakukan studi pemanfaatan energi menggunakan turbin Savonius pada kecepatan rendah melalui wind tunne/yang menghasilkan peningkatan $C_{p}$ sebesar $32,3 \%$. Ide pemusatan aliran tersebut juga dilakukan oleh beberapa peneliti dengan menambahkan plat deflektor atau Omni Directional Guide Vanes (ODGV) pada turbin. Turbin Savonius dengan sudut pengarah deflektor $0^{\circ}$ aliran mampu menghasilkan nilai $C_{p}$ antara 0,04-0,09 dan TSR berkisar 0,07-0,093 (Prasetyo et al., 2018). Octauria, Nindito, dan Saputra (2021) melakukan studi penambahan pengarah berjenis ODGV terhadap turbin Darrieus yang berbasis lift force (gaya angkat), sehingga mampu meningkatkan hasil coefficient of power $\left(C_{p}\right)$. Pengukuran dilakukan di $x / B=0,5$ (tengah saluran) dengan pertimbangan karena di posisi tengah saluran memiliki kecepatan yang lebih tinggi dan semakin mengecil mendekati dinding dan dasar saluran (Nindito, Istiarto, dan Kironoto, 2008).

Studi terdahulu tentang pemusatan aliran pada turbin menggunakan ODGV ditunjukkan pada Gambar 1. Alexander dan Santhanakrishnan (2017) melakukan inovasi terhadap jumlah rectifier dengan variasi 6, 12 dan 24 buah (Gambar 1a). Pengurangan jumlah blade ODGV menyebabkan penurunan performa turbin. Tekanan yang berbeda membuat aliran tidak sepenuhnya tersalurkan menuju stator. Salim et al., (2015) melakukan eksperimen terhadap desain tilt angle rectifier pada guide vanes (Gambar $1 \mathrm{~b}$ ). Variasi tilt angle rectifier yang digunakan adalah $15^{\circ}, 30^{\circ}$ dan $45^{\circ}$. Desain tanpa variasi sudut menghasilkan nilai $C_{p}$ maksimum 0,018 dengan Tip Speed Ratio(TSR) sebesar 0,48. Penambahan tilt angle terhadap guide vanes menyebabkan menurunnya coefficient of torque $\left(C_{T}\right)$ ketika kecepatannya ditingkatkan. Hasil studi didapat bahwa guide vanes dengan desain tilt angle rectifier $45^{\circ}$ meningkatkan coefficient of power $\left(C_{p}\right)$ sebesar $65,89 \%$ lebih tinggi dibandingkan turbin tanpa guide vanes. 


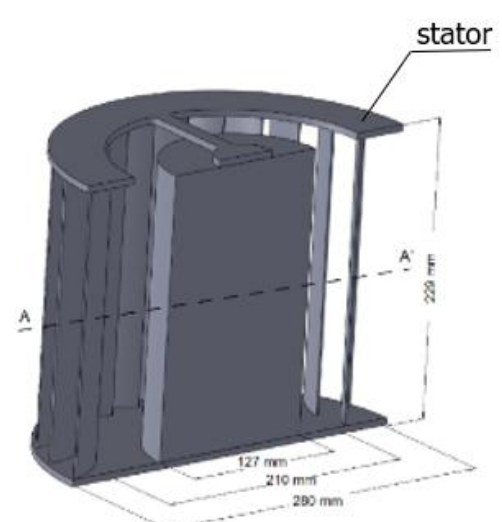

(a)

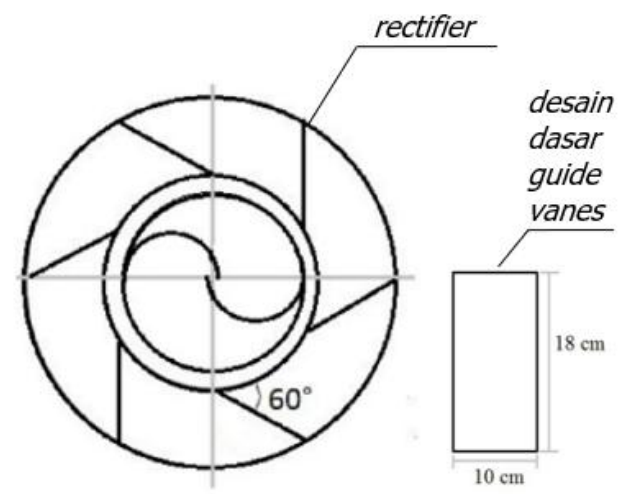

(b)

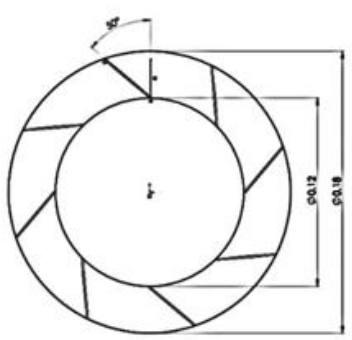

(c)

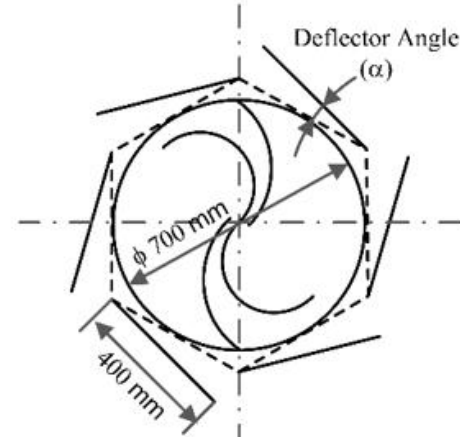

(d)

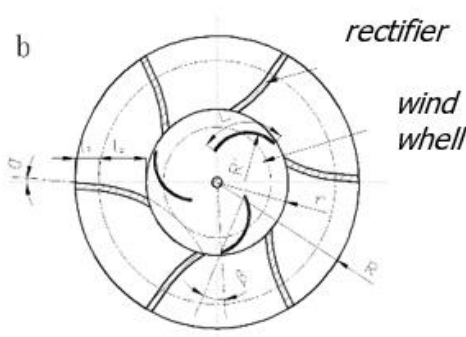

(e)

Gambar 1. Pemusatan aliran pada turbin Savonius: (a) Skema model stator ODGV (Alexander dan Santhanakrishnan, 2017), (b) Turbin Savonius dan guide vanes (Salim et al., 2015), (c) Parameter geometris ODGV (Wicaksono dan Tjahjana, 2017), (d) Sudut deflektor $(\alpha)$ guide vanes pada turbin Savonius

(Adiwidodo et al., 2020) dan (e) Prototipe turbin angin sumbu vertical (Tang et al., 2012)

Berdasarkan studi Wicaksono dan Tjahjana (2017), diketahui bahwa penambahan ODGV terhadap turbin Savonius dapat mengatasi masalah blade sisi cekung yang menghasilkan torsi negatif (Gambar 1c). Tekanan negatif yang dimiliki blade turbin Savonius dapat diminimalkan dengan menggunakan ODGV sehingga menambah kecepatan turbin berotasi. Adiwidodo et al., (2020) menggunakan aplikasi CFD dalam pengujian terhadap turbin Savonius (Gambar 1d). Peningkatan kecepatan turbin dengan melakukan penambahan variasi deflektor $15^{\circ}$ mampu meningkatkan perolehan nilai torsi, namun ketika sudut deflektor diperbesar maka nilai torsi akan berkurang. Penambahan jumlah blade dapat meningkatkan kecepatan aliran fluida di sekitar blade. Penggunaan deflektor dapat mengurangi hambatan yang terjadi pada aliran. Sudut deflektor tertentu tidak dapat menghasilkan nilai torsi maksimum. Torsi maksimum didapatkan dengan sudut deflektor yang lebih besar dengan simulasi kecepatan aliran yang lebih tinggi. Tang et al., (2012) melakukan inovasi dengan penambahan guide vanes terhadap turbin sumbu vertikal Savonius dengan menggunakan simulasi CFD (Gambar 1e). Torsi mengalami peningkatan saat mendapat tekanan yang besar pada kedua sisi blade. Penambahan guide vanes menghasilkan $C_{p}$ maksimum 0,3375 dan TSR sebesar 0,8 lebih besar dari turbin Savonius tanpa guide vanes. Hasil yang didapatkan menunjukkan bahwa turbin Savonius dengan menggunakan guide vanes dapat meningkatkan performa lebih besar dibandingkan dengan turbin Savonius konvensional. 
Beberapa parameter untuk mengetahui performa turbin antara lain coefficient of power $\left(C_{p}\right)$, coefficient of torque $\left(C_{T}\right)$ dan Tip Speed Ratio (TSR). Coefficient of torque $\left(C_{T}\right)$ didefinisikan sebagai rasio torsi aktual oleh turbin yang tersedia dalam aliran (Alom dan Saha, 2018).

$$
C_{\tau}=\frac{T_{\text {turbine }}}{\frac{1}{2} \rho A V^{2} R}
$$

dengan: $T_{\text {turbine }}=$ gaya yang dihasilkan oleh rotasi turbin, $\rho=$ massa jenis air $\left(\mathrm{kg} / \mathrm{m}^{3}\right), A=$ luas daerah bidang tangkap $\left(\mathrm{m}^{2}\right), V=$ kecepatan aliran $(\mathrm{m} / \mathrm{s})$ dan $\mathrm{R}=$ jari-jari turbin $(\mathrm{m})$.

Coefficient of power $\left(C_{P}\right)$ merupakan energi yang dihasilkan dari turbin sebagai bagian dari energi air total yang melewati area putaran turbin (Alom dan Saha, 2018).

$$
C_{p}=\frac{\tau \omega}{\frac{1}{2} \rho A V^{3}}
$$

dengan: $\tau=$ torsi yang dihasilkan oleh turbin $(\mathrm{Nm})$ dan $\omega=$ kecepatan sudut (rad/s).

Kecepatan sudut ditunjukkan oleh persamaan berikut (Mahmoud et al., 2012).

$$
\omega=\frac{2 \pi n}{60}
$$

dengan: $n$ merupakan jumlah putaran per menit yang diperoleh turbin (RPM)

Performa turbin Savonius dapat dilihat dari nilai Tip Speed Ratio (TSR) (Salim et al. 2015).

$$
T S R=\frac{\omega R}{V}
$$

Berdasarkan uraian di atas, turbin Savonius menghasilkan nilai torsi negatif yang cukup tinggi dikarenakan sisi cekung pada blade turbin Savonius, sehingga pemusatan aliran menjadi penting dilakukan. Salah satu cara untuk meningkatkan performa turbin Savonius adalah dengan menambahkan ODGV, namun seberapa besar pengaruh lebar rectifier guide vane menjadi perlu dipertimbangkan. Untuk itu perlu studi eksperimental yang bertujuan untuk mengetahui seberapa besar pengaruh penambahan guide vanes pada turbin Savonius terhadap performa turbin saat dilakukan variasi lebar rectifier. Tujuan utamanya supaya mampu meningkatkan jumlah aliran yang masuk ke turbin, meminimalkan torsi negatif dan mengoptimalkan torsi positif dengan mengarahkan air yang memasuki rotor turbin, sehingga kinerja turbin meningkat.

\section{METODE PENGUJIAN}

Studi ini menggunakan metode ekperimental dengan cara menguji turbin Savonius dengan penambahan fitur guide vanes (rectifier dan end plate). Lebar rectifier $(L)$ divariasikan berdasarkan ukuran jari-jari turbin Savonius. Rectifier dipasangkan dengan sudut $90^{\circ}$ (tegak lurus terhadap turbin Savonius), sedangkan dimensi end plate menyesuaikan lebar rectifier $(L)$, seperti yang ditunjukkan pada Gambar 2 berikut. 

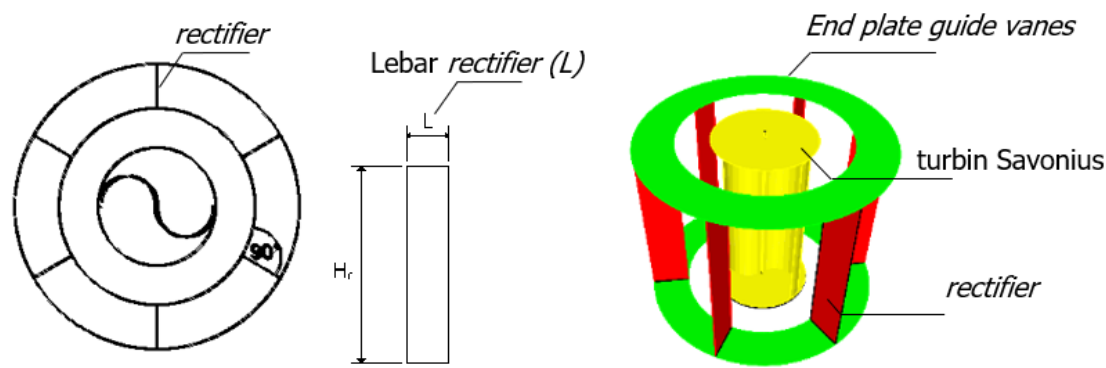

Gambar 2. Desain sudut $\left(90^{\circ}\right)$ dan variasi lebar rectifier (L) guide vane

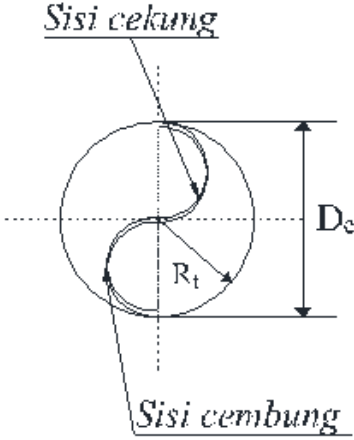

(a)

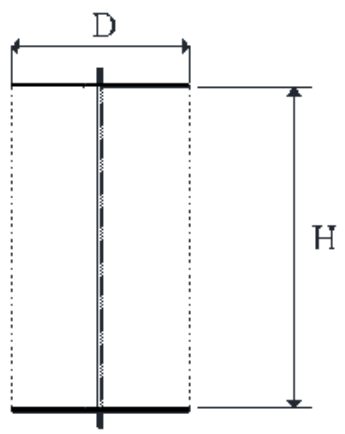

(b)

Gambar 3. Sketsa desain turbin Savonius: (a) tampak atas, (b) tampak samping

Pada Gambar 3a menunjukkan desain turbin Savonius tampak atas. Turbin Savonius memiliki karakteristik blade sisi cembung dan cekung, dengan De adalah diameter bladeturbin Savonius dan $R_{\mathrm{t}}$ merupakan jari-jari turbin. Gambar $3 \mathrm{~b}$ memperlihatkan tampak samping turbin Savonius, dengan $\mathrm{D}$ adalah diameter end plate turbin dan $\mathrm{H}$ adalah tinggi blade.

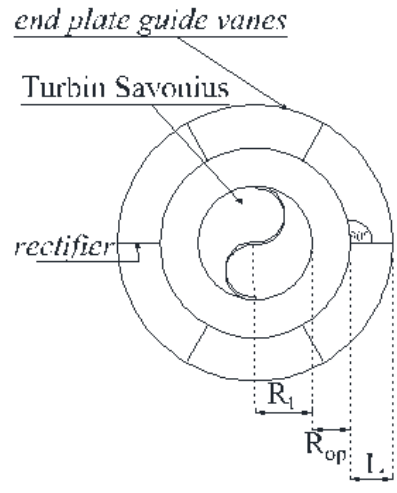

(a)

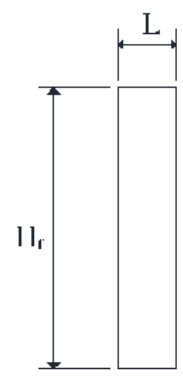

(b)

\section{Gambar 4. Desain turbin Savonius dengan guide vanes: (a) Skematik turbin Savonius} dengan guide vanes dan (b) Dimensi rectifier

Gambar 4a menunjukkan tampak atas dari skematik turbin Savonius dengan menggunakan guide vanes (rectifier dan end plate). Rectifier dipasangkan dengan sudut $90^{\circ}$ (tegak lurus terhadap turbin Savonius). $\mathrm{R}_{\mathrm{t}}$ adalah jari-jari turbin yang diukur dari titik pusat sampai sisi terluar dari end plate turbin Savonius. Rop adalah jari-jari opening yang diukur dari jari-jari terluar turbin sampai bagian dalam end plate dari guide vanes. Gambar $4 \mathrm{~b}$ menunjukkan dimensi rectifier, di mana $\mathrm{H}_{\mathrm{r}}$ adalah tinggi rectifier dan $\mathrm{L}$ adalah lebar dari rectifier.

\section{Tabel 1. Parameter desain turbin Savonius dan guide vanes}


Nur Ichsan, Dwi Anung Nindito, Raden Haryo Saputra

\begin{tabular}{lcc}
\multicolumn{1}{c}{ Parameter } & Simbol & Dimensi \\
\hline Diameter blade & $\mathrm{D}$ & $12 \mathrm{~cm}$ \\
\hline Jari - jari turbin & $\mathrm{Rt}_{\mathrm{t}}$ & $6 \mathrm{~cm}$ \\
\hline Diameter end plate & $\mathrm{De}_{\mathrm{e}}$ & $12 \mathrm{~cm}$ \\
\hline Tinggi turbin & $\mathrm{H}$ & $21,6 \mathrm{~cm}$ \\
\hline Jari - jari opening & $\mathrm{Rop}_{\mathrm{op}}$ & $4 \mathrm{~cm}$ \\
\hline Tinggi rectifier & $\mathrm{H}_{\mathrm{r}}$ & $21,6 \mathrm{~cm}$ \\
\hline Lebar rectifier & $\mathrm{L}$ & $3 / 4 \mathrm{R}_{\mathrm{t}}, 1 / 2 \mathrm{R}_{\mathrm{t}}, 3 / 4 \mathrm{R}_{\mathrm{t}} \mathrm{cm}$ \\
\hline
\end{tabular}

Tabel 1 menunjukkan parameter desain turbin Savonius dan guide vanes yang diujikan. Berdasarkan Tabel 1, maka dibuatlah bentuk dari turbin Savonius dan guide vanes.

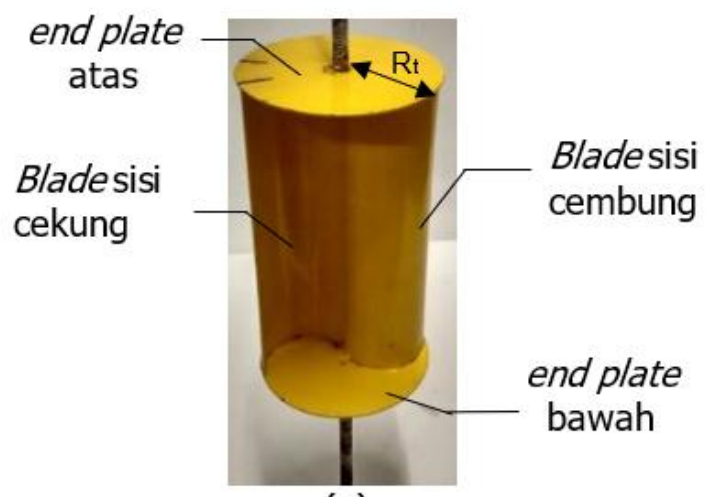

(a)

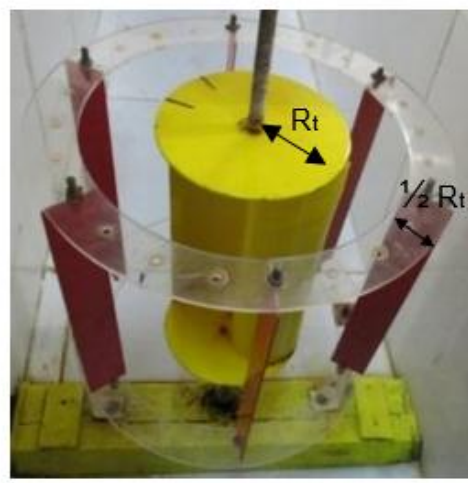

(c)

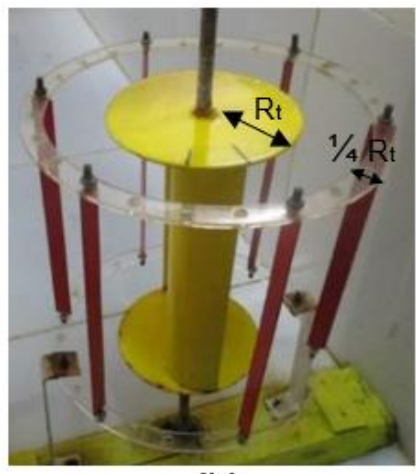

(b)

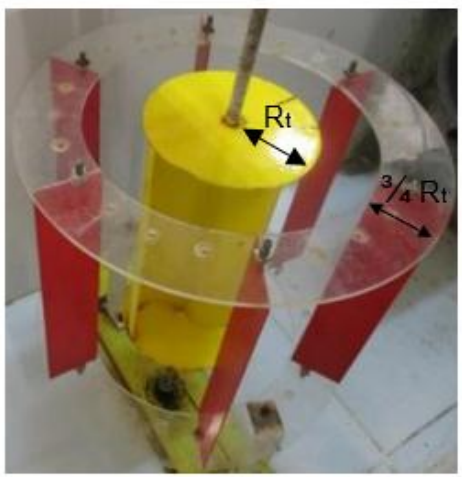

(d)

Gambar 5. (a) Turbin Savonius yang diujikan, (b) Lebar rectifier $L=1 / 4 R_{t}$ ，(c) Lebar rectifier $L=1 / 2 R_{t}$, (d) lebar rectifier $L=3 / 4 R_{t}$

Gambar 5a menunjukkan desain dari turbin Savonius yang akan diujikan pada saluran prismatik (flume). Gambar 5b, Gambar 5c dan Gambar 5d masing-masing menunjukkan variasi lebar rectifier $(L)$ yang digunakan, yaitu $L=1 / 4 \mathrm{R}_{\mathrm{t}}, L=1 / 2 \mathrm{R}_{\mathrm{t}}$ dan $L=3 / 4 \mathrm{R}_{\mathrm{t}}$ dengan $\mathrm{R}_{\mathrm{t}}$ adalah jari-jari turbin Savonius. Ukuran end plate guide vanes menyesuaikan dengan lebar rectifier $(L)$. 


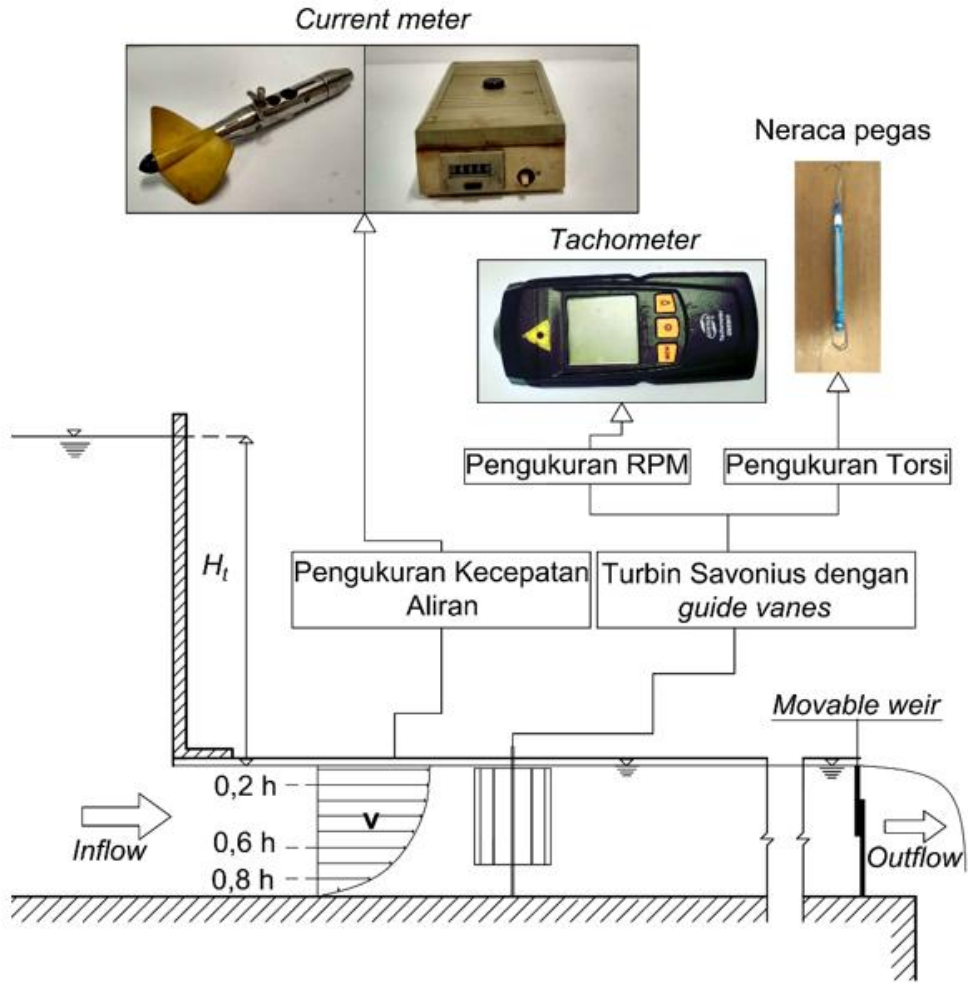

(a)

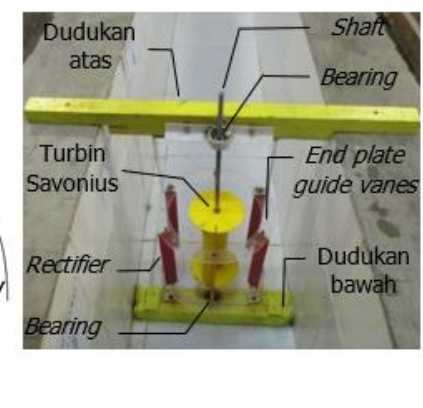

(b)

Gambar 6. Skematik pengujian eksperimental: (a) saluran prismatik (flume) dan (b) posisi pengujian turbin Savonius

Pengujian turbin Savonius dan turbin Savonius dengan guide vanes dilakukan pada saluran prismatik (flume) seperti yang terlihat pada skema Gambar 6a. Ukuran flume yang digunakan adalah tinggi $\mathrm{H}_{\mathrm{f}}=0,44 \mathrm{~m}$, lebar $\mathrm{L}_{\mathrm{f}}=0,46 \mathrm{~m}$ dan kedalaman aliran saat pengujian $\mathrm{H}_{\mathrm{a}}=0,42 \mathrm{~m}$. Variasi beda tinggi $\left(H_{t}\right)$ permukaan air di tandon dengan permukaan air di saluran prismatik (flume) menyebabkan variasi kecepatan aliran yang mengalir di flume. Movable weir berfungsi untuk menjaga ketinggian air pada permukaan saluran prismatik sehingga alirannya steady flow. Rotasi Per Menit (RPM) diukur menggunakan alat tachometer tipe GM8905. Torsi $(\tau)$ diperoleh dari nilai gaya $(\mathrm{N})$ yang dihasilkan neraca pegas dikalikan panjang lengan $(\mathrm{m})$. Pembacaan kecepatan aliran diukur dengan alat current meter seri SEBA-Universal Current meter F1. Dari pengukuran profil distribusi kecepatan vertikal pada $\mathrm{x} / \mathrm{B}=0,5$ (tengah saluran) diperoleh kecepatan rerata tampang saluran. Gambar $6 \mathrm{~b}$ menunjukkan turbin Savonius menggunakan guide vanes dengan variasi lebar rectifier $(L)$ yang diujikan pada studi ini. Posisi rectifier guide vanes adalah $90^{\circ}$ tegak lurus mengelilingi seluruh bagian turbin Savonius dengan tujuan meningkatkan kecepatan aliran menuju blade turbin dan mengurangi momen hambatan yang bekerja pada blade turbin dengan cara menyesuaikan arah aliran.

\section{HASIL DAN PEMBAHASAN}

Uji eksperimental dilakukan pada range kecepatan 0,1111 m/s sampai dengan 0,1415 m/s. Gambar 7a memperlihatkan hubungan Rotasi Per Menit (RPM) dengan kecepatan aliran ( $v$ ). Hasil pengujian dengan range kecepatan yang sama diperoleh nilai Rotasi Per Menit (RPM) turbin Savonius sebesar 98,41-130,25. Turbin Savonius menggunakan guide vanes dengan variasi lebar rectifier $L=1 / 4 \mathrm{R}_{\mathrm{t}}$ memperoleh nilai RPM sebesar 96,54-127,29. Untuk lebar rectifier $L=1 / 2 \mathrm{R}_{\mathrm{t}}$ menghasilkan nilai RPM antara 97,38-127,75. Sedangkan hasil untuk lebar 
rectifier $L=3 / 4 \mathrm{R}_{\mathrm{t}}$ diperoleh nilai RPM antara 96,13-128,93. Berdasarkan Gambar 7a, gradien perubahan kecepatan aliran ( $v$ ) terhadap RPM untuk variasi lebar rectifier $L=3 / 4 \mathrm{R}_{\mathrm{t}}$ lebih tinggi dibandingkan variasi lebar rectifier $(L)$ lainnya.

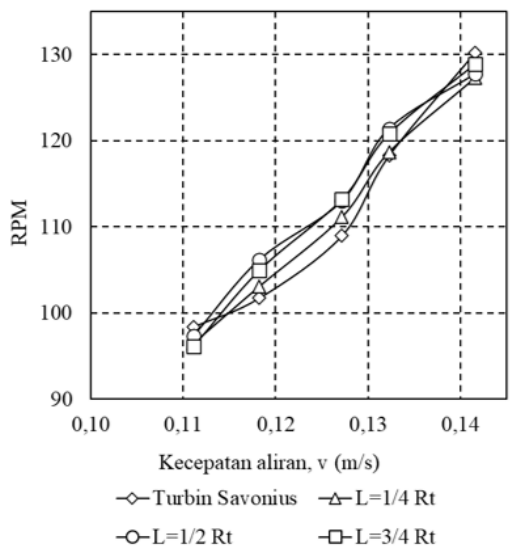

(a)

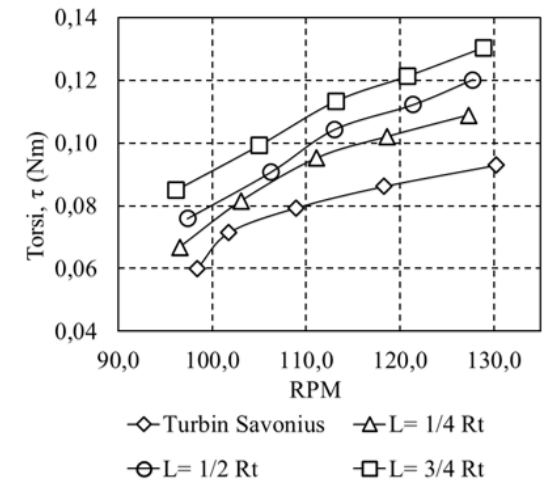

(b)

\section{Gambar 7. (a) Grafik hubungan RPM dan Kecepatan aliran, $v(\mathrm{~m} / \mathrm{s})$ dan (b) Grafik hubungan RPM dan Torsi (Nm)}

Gambar 7b menunjukkan hubungan RPM dan torsi $(\tau)$ pada turbin Savonius dan turbin Savonius menggunakan guide vanes dengan variasi lebar rectifier $(L)$. Turbin Savonius menghasilkan torsi $(\tau)$ antara 0,0601-0,0929 Nm dan Rotasi Per Menit (RPM) berkisar 98,41130,25 . Guide vanes dengan variasi lebar rectifier $L=1 / 4 \mathrm{R}_{\mathrm{t}}$ memperoleh nilai RPM sebesar 96,54-127,29 dan torsi $(\tau)$ antara 0,0669-0,1088 Nm. Untuk guide vanes dengan lebar rectifier $L=1 / 2 \mathrm{R}_{\mathrm{t}}$ menghasilkan torsi $(\tau)$ dan RPM masing-masing antara 0,0759-0,1201 $\mathrm{Nm}$ dan 97,38-127,75. Untuk variasi dengan lebar rectifier $L=3 / 4 \mathrm{R}_{\mathrm{t}}$ menghasilkan nilai RPM berkisar antara 96,13-128,93 dan nilai torsi $(\tau)$ antara 0,0850-0,1303 Nm. Berdasarkan Gambar 7b, gradien perubahan RPM terhadap nilai torsi $(\tau)$ variasi lebar rectifier $L=3 / 4 \mathrm{R}_{\mathrm{t}}$ lebih tinggi dibandingkan variasi rectifier lainnya.

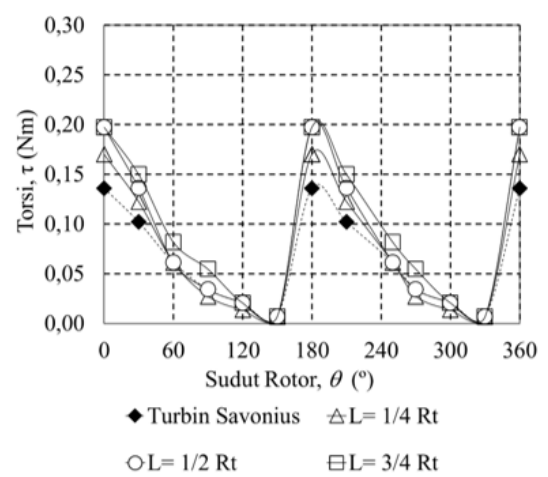

(a) $v=0,1111 \mathrm{~m} / \mathrm{s}$

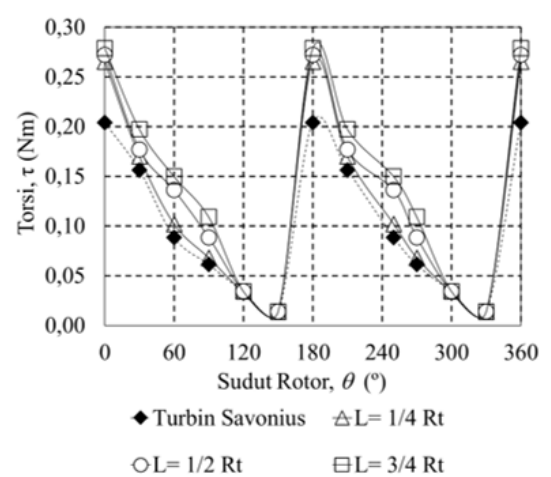

(b) $v=0,1415 \mathrm{~m} / \mathrm{s}$

Gambar 8. Grafik hubungan torsi $(\tau)$ terhadap sudut rotor $(\theta)$ dengan kecepatan aliran $(v)$ 
Gambar 8 menunjukkan perbandingan torsi $(\tau)$ dengan sudut $\operatorname{rotor}(\theta)$ satu putaran penuh. Pengujian dilakukan pada variasi kecepatan aliran $v=0,1111 \mathrm{~m} / \mathrm{s}$ (Gambar 8a) dan kecepatan aliran $v=0,1415 \mathrm{~m} / \mathrm{s}$ (Gambar 8b). Hasil yang diperoleh menunjukkan bahwa rasio penambahan kecepatan aliran menghasilkan peningkatan torsi $(\tau)$ pada saat sudut rotor $(\theta) 0^{\circ}$, $180^{\circ}$ dan $360^{\circ}$. Pada posisi sudut rotor $(\theta)$ tersebut, sisi cekung turbin Savonius berada pada posisi tegak lurus terhadap arah aliran. Hal ini menyebabkan tangkapan aliran terjadi secara optimal. Pada kondisi kecepatan aliran $v=0,1415 \mathrm{~m} / \mathrm{s}$ (Gambar $8 \mathrm{~b}$ ), pada sudut $180^{\circ}-210^{\circ}$ dan $330^{\circ}-360^{\circ}$ menunjukkan peningkatan torsi $(\tau)$ akibat penambahan guide vanes dibandingkan turbin Savonius tanpa guide vanes. Desain turbin Savonius menggunakan guide vanes dengan variasi lebar rectifier $L=1 / 4 \mathrm{R}_{\mathrm{t}}, L=1 / 2 \mathrm{R}_{\mathrm{t}}$ dan $L=3 / 4 \mathrm{R}_{\mathrm{t}}$ masing-masing menghasilkan peningkatan torsi $(\tau)$ sebesar $29,9 \%, 33,3 \%$, dan $36,3 \%$.

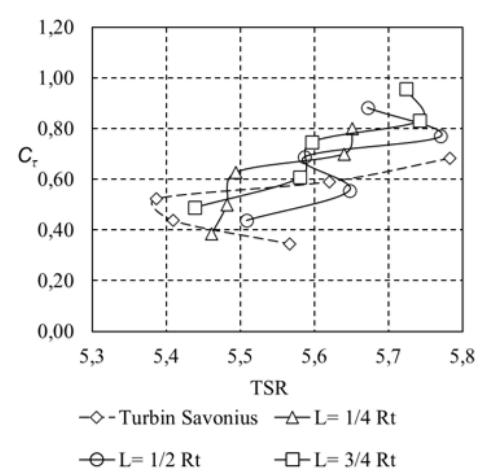

(a)

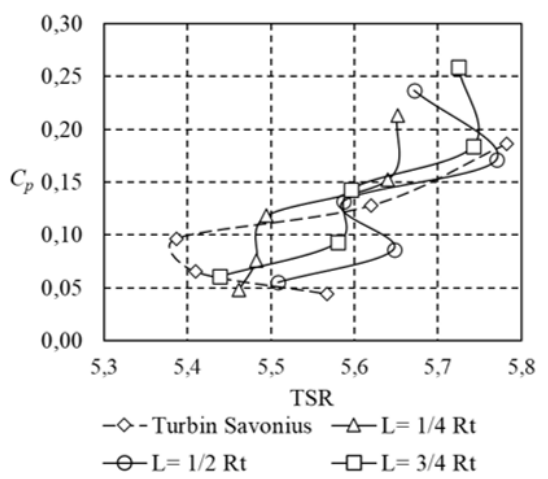

(b)

Gambar 9. (a) Grafik hubungan coefficient of torque $\left(C_{T}\right)$ dan Tip Speed Rasio (TSR) dan (b) Grafik hubungan coefficient of power $\left(C_{p}\right)$ dan Tip Speed Ratio

Gambar 9a menunjukkan grafik hubungan $C_{T}$ dan TSR pada pengujian turbin Savonius dan turbin Savonius menggunakan guide vanes. Turbin Savonius menghasilkan coefficient of torque $\left(C_{T}\right)$ dan Tip Speed Ratio (TSR) masing-masing antara 0,35-0,68 dan 5,39-5,78. Turbin Savonius menggunakan guide vanes dengan variasi lebar rectifier $L=1 / 4 \mathrm{R}_{\mathrm{t}}$ menghasilkan $C_{T}$ berkisar 0,39-0,80 dan TSR antara 5,46-5,65. Variasi rectifier $L=1 / 2 \mathrm{R}_{\mathrm{t}}$ memperoleh nilai TSR antara 5,51-5,77 dan $C_{T}$ berkisar 0,44-0,88. Variasi dengan lebar rectifier $L=3 / 4 \mathrm{R}_{\mathrm{t}}$ memperoleh nilai coefficient of torque $\left(C_{T}\right)$ antara 0,49-0,96 dan TSR berkisar antara 5,445,72 . Berdasarkan Gambar $9 a$, lebar rectifier $L=3 / 4 \mathrm{R}_{\mathrm{t}}$ menghasilkan coefficient torque $\left(C_{T}\right)$ lebih tinggi dibandingkan variasi lebar rectifier $(L)$ lainnya. Persamaan 1 menjelaskan nilai coefficient torque $\left(C_{T}\right)$ dipengaruhi oleh torsi $(\tau)$ yang dihasilkan. Semakin tinggi nilai torsi $(\tau)$ yang dihasilkan maka nilai $C_{T}$ akan meningkat. Gambar 9b menunjukkan pengujian pada turbin Savonius dan turbin Savonius menggunakan guide vanes yang ditunjukkan dari hubungan $C_{p}$ dan TSR. Turbin Savonius menghasilkan nilai coefficient of power $\left(C_{p}\right)$ antara $0,04-0,19$. Penambahan guide vanes dengan variasi lebar rectifier $L=1 / 4 \mathrm{R}_{\mathrm{t}}$ menghasilkan $C_{p}$ antara 0,050,21 , dan nilai $C_{p}$ dengan lebar rectifier $L=1 / 2 \mathrm{R}_{\mathrm{t}}$ berkisar antara 0,06-0,24. Variasi untuk lebar rectifier $L=3 / 4 \mathrm{R}_{\mathrm{t}}$ menghasilkan nilai $C_{p}$ antara 0,06-0,26. Berdasarkan Gambar 9b, lebar rectifier $L=3 / 4 \mathrm{R}_{\mathrm{t}}$ menghasilkan nilai coefficient of power $\left(C_{P}\right)$ lebih tinggi dibandingkan 
variasi rectifier lainnya. Hal ini diketahui dari persamaan 2, nilai $C_{p}$ akan meningkat seiring dengan meningkatnya perolehan nilai torsi $(\tau)$. Gambar $9 \mathrm{~b}$ menunjukkan perolehan nilai torsi $(\tau)$ dengan lebar rectifier $L=3 / 4 \mathrm{R}_{\mathrm{t}}$ lebih tinggi dibandingkan variasi lebar rectifier $(L)$ lainnya.

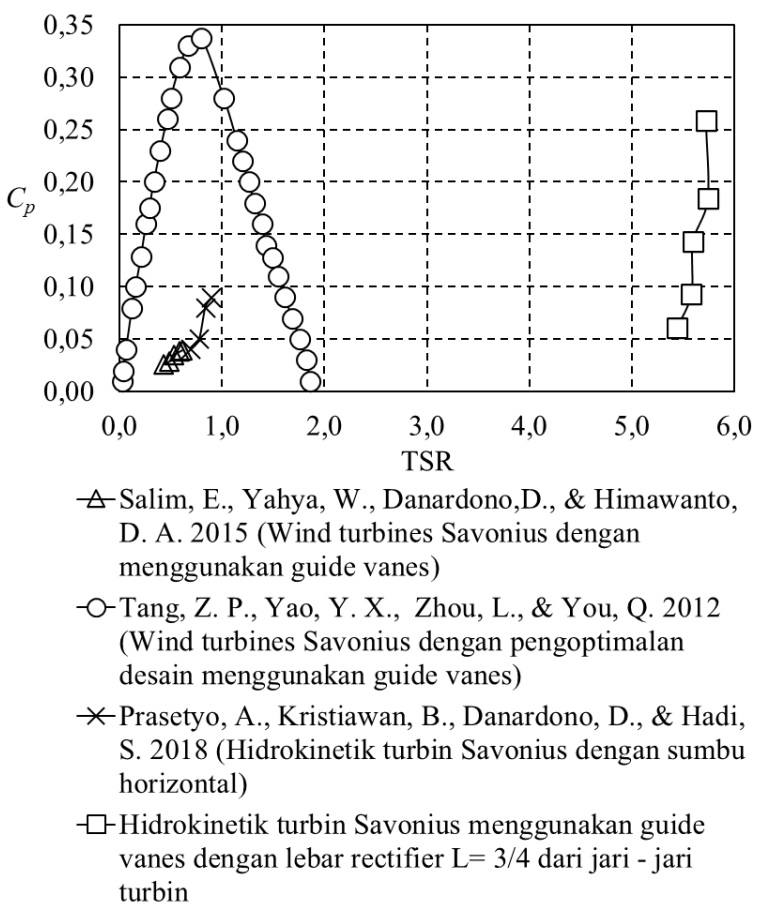

\section{Gambar 10. Perbandingan nilai $C_{p}$ dan TSR turbin Savonius menggunakan guide vanes dengan studi terdahulu}

Berdasarkan Gambar 10, Prasetyo et al., (2018) melakukan pengujian terhadap turbin Savonius dengan memasangkan deflektor agar dapat memusatkan aliran. Prasetyo et al., (2018) memperoleh nilai $C_{p}$ turbin Savonius adalah 0,04-0,09 dan TSR sebesar 0,07-0,93. Salim et al., (2015) yang menggunakan guide vanes dengan sudut $60^{\circ}$ menghasilkan coefficient of power $\left(C_{p}\right)$ dan TSR masing-masing antara 0,018 dan 0,48. Berdasarkan Gambar 10, turbin Savonius menggunakan guide vanes dengan variasi lebar rectifier $L=3 / 4 R_{t}$ menghasilkan performa coefficient of power $\left(C_{p}\right)$ dan nilai Tip Speed Ratio (TSR) yang lebih tinggi dibandingkan hasil Prasetyo et al., (2018) dan Salim et al., (2015). Tang et al., (2012) melakukan uji coba terhadap guide vanes, hasil studi memperoleh nilai $C_{p}$ maksimum 0,3375 dan TSR sebesar 0,8. Berdasarkan Gambar 10, bahwa turbin Savonius menggunakan guide vanes dengan variasi lebar rectifier $L=3 / 4 \mathrm{R}_{\mathrm{t}}$ memiliki nilai coefficient of power $\left(C_{p}\right)$ lebih kecil, akan tetapi nilai Tip Speed Ratio (TSR) yang dihasilkan lebih tinggi dibandingkan Tang et al., (2012).

\section{KESIMPULAN}

Dalam studi ini beberapa pengujian terhadap lebar rectifier telah dilakukan. Variasi lebar rectifier $(L)$ yang digunakan dalam studi ini yaitu $1 / 4 \mathrm{R}_{\mathrm{t}}, 1 / 2 \mathrm{R}_{\mathrm{t}}$ dan $3 / 4 \mathrm{R}_{\mathrm{t}}$, dimana $\mathrm{R}_{\mathrm{t}}$ adalah jarijari turbin Savonius. Variasi lebar rectifier $(L)$ yang menghasilkan kinerja lebih baik terhadap turbin Savonius adalah lebar rectifier $L=3 / 4 \mathrm{R}_{\mathrm{t}}$. Variasi lebar rectifier $L=3 / 4 \mathrm{R}_{\mathrm{t}}$ memperoleh coefficient of power $\left(C_{p}\right)$ lebih tinggi dibandingkan dengan turbin Savonius tanpa 
menggunakan guide vanes. Penambahan guide vanes dengan variasi lebar rectifier $(L)$ menyebabkan penurunan terhadap nilai Rotasi Per Menit (RPM) turbin Savonius pada saat terjadi peningkatan kecepatan aliran. Guide vanes dengan variasi lebar rectifier $L=1 / 4 R_{t}$, $L=1 / 2 \mathrm{R}_{\mathrm{t}}$ dan $L=3 / 4 \mathrm{R}_{\mathrm{t}}$ masing-masing menghasilkan peningkatan torsi $(\tau)$ sebesar $29,9 \%$, $33,3 \%$, dan $36,3 \%$. Variasi lebar rectifier $L=3 / 4 \mathrm{R}_{\mathrm{t}}$ menghasilkan nilai coefficient torque $\left(C_{T}\right)$ lebih tinggi dibandingkan variasi rectifierlainnya. Studi selanjutnya dapat melakukan penelitian mengenai pengaruh lebar rectifier $(L)$ berdasarkan tinggi dan luas tangkap dari turbin Savonius, hal ini menarik diteliti lebih lanjut untuk mendapatkan kinerja turbin yang optimum.

\section{DAFTAR PUSTAKA}

Adiwidodo, S., Wahyudi, B., Yudiyanto, E., Subagiyo, S., Hartono, M., \& Baananto, F. (2020). Simulation Study of Savonius Tandem Blade Wind Turbine Using an Adjustable Deflector. IOP Conference Series: Materials Science and Engineering, 732(1), 012093.

Alexander, A. S., \& Santhanakrishnan, A. (2017). Trapped Cylindrical Flow With Multiple Inlets for Savonius Vertical Axis Wind Turbines. Journal of Fluids Engineerinng, 1-26.

Alom, N., \& Saha, U. K. (2018). Four Decades of Research Into the Augmentation Techniques of Savonius Wind Turbine Rotor. Journal of Energi Resrources Technology, 140, 1-14.

Antomo, T., Kamiana, I. M., \& Nindito, D. A. (2020). Analisis Pengembangan Hidrokinetik Turbin Gorlov Akibat Penambahan Luas Bidang Tangkap. Teknika: Jurnal Sains dan Teknologi, 16(02), 159-170. https://doi.org/10.36055/tjst.v16i2.9186

Elbatran, A. H., Yaakob, O. B., Ahmed, Y. M., \& Jalal, M. R. (2015). Novel Approach of Bidirectional Diffuser-Augmented Channels System for Enhancing Hydrokinetic Power Generation in Channels. Renewable Energy. Renewable Energy, 83, 809-819.

Kang, C., Liu, H., \& Yang, X. (2014). Review of Fluid Dynamics Aspects of Savonius-RotorBased Vertical-Axis Wind Rotors. Renewable and Sustainable Energy Reviews, 33, 499508.

Mahmoud, N. H., El-Haroun, A. A., Wahba, E., \& Nasef, M. H. (2012). An Experimental Study on Improvement of Savonius Rotor Performance. Alexandria Engineering Journal, 51(1), 19-25.

Nindito, D. A., \& Kamiana, I. M. (2010). Perencanaan Model PLTA Skala Kecil Berbasis Teknologi Lokal Di Daerah Pemukimam Tepi Sungai. PROTEKSI (Program Studi Teknik Sipil), II(02), 1-7.

Nindito, D. A., Istiarto, dan Kironoto, B. A. (2008). Simulasi Numeris Tiga Dimensi Kantong Lumpur Bendung Sapon. Civil Engineering Forum Teknik Sipil, XVIII(1), 712-724.

Octauria, E. P., Nindito, D. A., \& Saputra, R. H. (2021). Uji Eksperimental Pengaruh Sudut Omni Directional Guide Vanes Terhadap Performa Turbin Hidrokinetik Darrieus. EKSERGI Jurnal Teknik Energi, 172), 95-108. https://doi.org/10.32497/eksergi.v17i2.2581

Prasetyo, A., Kristiawan, B., Danardono, D., \& Hadi, S. (2018). The Effect of Deflector Angle in Savonius Water Turbine with Horizontal Axis on the Power Output of Water Flow in Pipe. Journal of Physics: Conference Series, 1-6.

Pratama, A., Nindito, D. A., \& Saputra, R. H. (2021). Studi Eksperimental Sistem Pengarah Aliran Pada Turbin Hidrokinetik Archimedes Spiral. Jurnal Teknik, 19(1), 1-11. https://doi.org/10.37031/jt.v191.145

Roy, S., Mukherjee, P., \& Saha, U. K. (2014) Aerodynamic Performance Evaluation of A Novel Savonius-Style Wind Turbine Unde An Oriented Jet. ASME 2014 Gas Turbine India Conference, 1-7. 
Salim, E., Yahya, W., Danardono, D., \& Himawanto, D. A. (2015). A Study of the Influence of Guide Vane Design to Increase Savonius Wind Turbine Performance. Modern Applied Science, $9(11), 222$.

Tang, Z. P., Yao, Y. X., Zhou, L., \& Yao, Q. (2012). Optimal Design of a New Type of Savonius Rotor Using Simulation Analysis. Key Engineering Materials, 499, 120-125.

Wardani, C. S., Nindito, D. A., \& Jaya, A. R. (2020). Inovasi dan Desain Turbin Hidrokinetik Darrieus Berdasarkan Bentuk Distribusi Kecepatan Aliran. Media IImiah Teknik Sipil, 9(1), 32-43. http://doi.org/10.33084/mits.v9i1.1771

Wicaksono, Y. A., \& Tjahjana, D. D. D. P. (2017). Computational Study: The Influence of Omni-Directional Guide Vane on the Flow Pattern Characteristic Around Savonius Wind Turbine. AIP Conference Proceedings, 1-4.

Yudistira, R., Nindito, D. A., \& Saputra, R. H. (2021). Kinerja Turbin Hidrokinetik Tornado Savonius. Jurnal Teknika: Jurnal Teoritis Dan Terapan Bidang Keteknikan, 4(2), 181186. https://doi.org/10.52868/jt.v4i2.2732

Yudistira, R., Nindito, D. A., \& Saputra, R. H. (2021). Uji Eksperimental Pengembangan Turbin Hidrokinetik Savonius Berdasarkan Bentuk Profil Distribusi Kecepatan Aliran. RekaRacana: Jurnal Teknik Sipil 71 1), 1-11. https://doi.org/10.26760/rekaracana.v7i1.215 